In type-III OI spinal deformity can be very severe. Finidori (Paris) ${ }^{4}$ regards spinal fusion as mandatory, often preceded by halocranial traction. No form of surgery corrects the severe shortening, including that of the upper segment, in type-III and type-IV OI. Growth hormone produced a sustained increase in linear growth rate in some children with type-IV OI (Marini, NIH, Bethesda), ${ }^{4}$ but it is too early to draw any conclusions from this study and work from Australia (Sillence) ${ }^{4}$ and Italy. ${ }^{8}$

Since sodium fluoride stimulates osteoblasts it is an obvious therapeutic candidate in OI; however, in a doubleblind placebo-controlled randomised study pulsed sodium fluoride was found to be ineffective in children with OI (Whyte, St Louis). ${ }^{4}$

In contrast, bisphosphonates selectively reduce bone resorption. Intermittent pamidronate (APD; an amino bisphosphonate) produces dense lines in the growing skeleton. ${ }^{9}$ In eight children with type-III or type-IV OI intravenous APD given at four- to six-month intervals increased bone mineral content and density, reduced bone resorption (assessed biochemically) and improved symptoms (Glorieux, Montreal).

Potentially, the most dramatic form of treatment in OI is gene replacement (Prockop, Philadelphia). ${ }^{4}$ In type-I OI this could involve stimulation of type-I collagen synthesis and in types II, III and IV replacement of the gene. The ethical and technical problems of correcting type-II OI mutations in utero are, at present, too great. In normal mice, injected stromal cells containing a human type-I collagen minigene may survive for a significant period but previous irradiation causes significant mortality. ${ }^{10}$ Replacement of the defective gene in human OI would also necessarily begin with destruction of the mutant stromal cells. Horwitz (Memphis) ${ }^{4}$ described the infusion of normal bone marrow into infants with severe type-III OI after previous ablation chemotherapy. If such normal stromal cells do engraft in the marrow, it is not known whether they will alter the phenotype.

Where should we go from here? The excitement of mutation discovery has declined and gene therapy seems far ahead. Many new osteotropic agents are now being developed, some as a spin-off from research on osteoporosis, and these may increase bone mass and possibly strength. We can no longer delay in assessing their effectiveness in OI by properly conducted clinical trials. Since OI is so phenotypically variable this is not easy and never will be.

ROGER SMITH

\section{REFERENCES}

1. Byers PH. Osteogenesis imperfecta. In: Royce PM, Steinmann B, eds. Connective tissue and its heritable disorders. First edition. New York: Wiley Liss Inc, 1993:317-50.

2. Smith R. Osteogenesis imperfecta: the brittle bone syndrome. Curr Orthop 1995;9:28-33.

3. Francomano CA, McIntosh I, Wilkin DJ. Bone dysplasias in man: molecular insights. Curr Opin Genet Dev 1996;6:301-8.

4. Sixth International Conference on Osteogenesis Imperfecta. Holland, September, 1996.

5. Smith R. Osteogenesis imperfecta: from phenotype to genotype and back again. Int J Exp Pathol 1994;75:233-41.

6. Paterson CR, Ogston SA, Henry RM. Life expectancy in osteogenesis imperfecta. Br Med J 1996;312:351.

7. McAllion SJ, Paterson CR. Causes of death in osteogenesis imperfecta. J Clin Path 1996;49:627-30.

8. Antoniazzi F, Bertoldo F, Mottes M, et al. Growth hormone treatment in osteogenesis imperfecta with quantitative defect of type I collagen synthesis. J Pediatr 1996;129:432-9.

9. Devogelaer JP, Malgham J, Maldague B, Nagant de Deuxchaisnes C. Radiological manifestations of bisphosphonate treatment with APD in a child suffering from osteogenesis imperfecta. Skeletal Radiol 1987;16:360-3.

10. Prockop DJ, Kivirikko KI. Collagens: molecular biology, diseases and potentials for therapy. Ann Rev Biochem 1995;65:403-34.

\title{
Bone allograft: a cause for concern?
}

Skeletal allograft is now widely used to restore bone stock especially during joint reconstruction and for limb salvage after tumour resection. Many patients have benefited and there is now a shortage of allograft in parts of the UK. Despite this popularity, a number of issues regarding its biology, processing and safety remain unresolved. Reports of graft-related failure and of complications such as infec-

F. H. Norman-Taylor, FRCS, Specialist Registrar in Trauma and Orthopaedics

R. N. Villar, FRCS, Consultant Orthopaedic Surgeon

Addenbrooke's Hospital NHS Trust, Hills Road, Cambridge CB2 2QQ, UK.

(C)1997 British Editorial Society of Bone and Joint Surgery 0301-620X/97/27492 \$2.00

J Bone Joint Surg [Br] 1997;79-B:178-80. tion, fracture and nonunion are relatively common.

Deep infection in an allograft is usually disastrous. Its occurrence has been shown to increase with the size of the graft $^{1}$ and may be seen in over $10 \%$ of massive allografts. ${ }^{2}$ It appears to be unrelated to preoperative contamination of the graft, and probably results from the complexity of the procedure and poor incorporation with dead bone behaving like a sequestrum. The incorporation process also appears to weaken the bone, predisposing to fracture. In a large series of massive allografts, Mankin and his co-workers reported an overall fracture rate of $19 \% .^{2}$ Without incorporation, allografts are essentially bony endoprostheses. The aim is peripheral union, but radiological nonunion can be expected in about $17 \%$. $^{2}$ Union is difficult to assess reliably on radiographs; postmortem analyses of acetabular structural grafts have shown little evidence of histological 
union, despite the appearance of radiological union. ${ }^{3}$ Acetabular reconstruction using solid allograft became popular after good early results ${ }^{4,5}$ had been reported, but eventual failure follows in up to $54 \%$ after the use of femoral heads. ${ }^{6,7}$ Single photon-emission CT (SPECT) has provided evidence of incorporation in only about two-thirds of such grafts. ${ }^{8}$ The results may be better than this when male femoral heads or cadaver bones are used, because of their better initial strength, ${ }^{9}$ but care must be taken to avoid reliance on the graft for mechanical support. ${ }^{10}$

The more recent technique using impaction of morsellised allograft has provided encouraging early results with few complications, ${ }^{11,12}$ and this is now widely used to restore bone stock during revision of hip replacements. Its application is restricted to situations in which it can be contained and impacted although, even then, the stability of the impacted bone has been questioned. ${ }^{13}$ Significant early migration has been reported, ${ }_{15}^{14}$ and it is likely that surgical technique, graft composition ${ }^{15}$ and choice of prosthesis ${ }^{16}$ are important. A number of animal and clinical biopsy specimens have suggested that incorporation is quite consistent. $^{17-19}$

Complete incorporation of bone allograft in a manner similar to autograft is clearly possible, ${ }^{20}$ but in practice the degree of incorporation is quite unpredictable. ${ }^{2,21}$ This variation may be related to antigenic disparity, notably between the cell-surface antigens of the major histocompatibility complex, although there is no clear clinical correlation, $^{22}$ and many grafts are essentially acellular. The links between the antigen in the bone and the biological responses to it are not known. ${ }^{20}$ The resorption of a graft is sometimes dramatic; this may well be due to an immune response. $^{21}$ Less aggressive resorption is a normal biological reaction to bone graft and is part of neovascularisation, ${ }^{22}$ but in allografts it probably contributes to fracture formation. $^{23}$ Tissue typing to try to reduce resorption and fracture is of uncertain value ${ }^{22}$ and would be very difficult to implement.

In the UK, the supply of allograft relies heavily on femoral heads obtained during primary hip replacement and the most common indication for its use is revision of this procedure. It has been estimated that this source of bone should be adequate to meet demand, ${ }^{24}$ but this may not be true since up to a half of the patients having primary hip replacement are not suitable donors, and a large proportion of donated femoral heads have to be discarded to meet current guidelines. ${ }^{25,26}$ Even with the present ratio of primary to revision surgery, many bone banks have difficulty in meeting demand. Cadaver donation is becoming a more important source of bone, and the harvesting of such bone is subject to similar guidelines as those for live bone. ${ }^{25,26}$ Live donors are requested to attend for second HIV and $\mathrm{HCV}$ antibody tests at 180 days after donation. Cadaver donors cannot do this, and screening therefore relies on a single test and an interview with the relatives, often under difficult circumstances. A recent survey of routine blood samples taken in London hospitals has shown an HIV carriage rate of 1 in 120 for men and 1 in 440 for women, ${ }^{27}$ and the transmission of viral and other diseases must remain a cause for concern. ${ }^{28,29}$ Bacterial contamination is also common, especially during cadaver harvesting, which is not always performed under the aseptic conditions of operating theatres. ${ }^{30}$

Sterilisation of grafts is therefore frequently used. The most popular method is gamma irradiation, in keeping with methods for other medical devices and equipment. The effective dose of radiation is that which will inactivate HIV, since lower doses are required for bacteria and other common viruses. Prions, ${ }^{31}$ some viruses and other potential, but as yet unknown, infective agents may be more resistant to irradiation. A dose of $25 \mathrm{kGy}$ is probably the minimum required to inactivate $\mathrm{HIV},{ }^{32}$ but more than $30 \mathrm{kGy}$ are recommended for its complete eradication. ${ }^{33}$ The adverse effects of such high doses of radiation on bone graft are well-established with respect to mechanical performance ${ }^{34}$ and osteoinductivity. ${ }^{35}$

Ethylene oxide sterilisation is not a popular alternative because residual gas may remain within the transplanted tissue and cause irritation. ${ }^{36}$ Pasteurisation is used by some centres. It is probably effective against $\mathrm{HIV}^{37}$, but falls short of sterilisation. Autoclaving, boiling and other methods damage the graft and are not suitable.

Reliance on terminal sterilisation does not obviate the need to reduce contamination, and also raises concerns about the implantation of dead bacteria and altered viral particles with the graft. Careful donor selection and safeguards to cover harvesting, processing and handling may be more appropriate, ${ }^{38}$ but the variation in present methods used by bone banks has implications for graft safety, graft function and the comparison of results.

Most published reports on this subject are from centres with many years of experience of bone allografting and can be expected to show the best results. Yet they reveal that allograft is somewhat unpredictable even in these units. Despite this, and concerns about its safety, the growing use of allograft for the restoration of skeletal tissue has been virtually unchallenged. If adequate and safe supplies can be maintained this is likely to be continued until alternative methods are found.

F. H. NORMAN-TAYLOR R. N. VILLAR

\section{REFERENCES}

1. Tomford WW, Thongphasuk J, Mankin HJ, Ferraro MJ. Frozen musculoskeletal allografts: a study of the clinical incidence and causes of infection associated with their use. J Bone Joint Surg [Am] 1990;72-A:1137-43.

2. Mankin HJ, Gebhardt MC, Jennings LC, Springfield DS, Tomford WW. Long-term results of allograft replacement in the management of bone tumours. Clin Orthop 1996;324:86-97.

3. Hooten JP, Engh CA, Heekin RD, Vinh TN. Structural bulk allografts in acetabular reconstruction: analysis of two grafts retrieved at post-mortem. J Bone Joint Surg [Br] 1996;78-B:270-5.

4. Jasty MJ, Harris WH. Total hip reconstruction using frozen femoral head allografts in patients with acetabular bone loss. Orthop Clin North Am 1987;18:291-9. 
5. Engh CA, Glassman AH, Griffin WL, Mayer JG. Results of cementless revision for failed cemented total hip arthroplasty. Clin Orthop 1988;235:91-110.

6. Jasty M, Harris WH. Salvage total hip reconstruction in patients with major acetabular bone deficiency using structural femoral head allografts. J Bone Joint Surg [Br] 1990;72-B:63-7.

7. Wilson MG, Nikpoor N, Aliabadi P, Poss R, Weissman BN. The fate of acetabular allografts after bipolar revision arthroplasty of the hip: a radiographic review. J Bone Joint Surg [Am] 1989;71-A:1469-79.

8. Shih C-H, Chen C-H, Tsai M-F, Tzen K-Y. Incorporation of allograft for acetabular reconstruction: single photon emission CT in 21 hip arthroplasties followed for 2.5-5 years. Acta Orthop Scand 1994;65:589-94

9. Paprosky WG, Magnus RE. Principles of bone grafting in revision total hip arthroplasty: acetabular technique. Clin Orthop 1994; 298:147-55.

10. Garbuz D, Morsi E, Mohamed N, Gross AE. Classification and reconstruction in revision acetabular arthroplasty with bone stock deficiency. Clin Orthop 1996;323:98-107.

11. Slooff TJJH, Buma P, Schreurs BW, et al. Acetabular and femoral reconstruction with impacted graft and cement. Clin Orthop 1996; 323:108-15

12. Gie GA, Linder L, Ling RSM, Timperley AJ. Contained morsellized allograft in revision total hip arthroplasty: a minimum five year follow up. J Bone Joint Surg [Br]1996;78-B:Supp 1:71.

13. Malkani AL, Voor MJ, Fee KA, Bates CS. Femoral component revision using impacted morsellised cancellous graft: a biomechanical study of implant stability. J Bone Joint Surg [Br] 1996;78-B:973-8.

14. Eldridge JD, Hubble MJ, Smith EJ, Learmonth ID. Massive subsidence following femoral impaction grafting. J Bone Joint Surg [Br] 1996;78-B:Supp II \& III:137.

15. Kuiper JH, Merry JC, Cheah K, et al. Early mechanical stability of impaction-grafted prosthesis: effects of surgical technique, implant design and graft composition. J Bone Joint Surg [Br] 1996;78-B:Supp II \& III: 136 .

16. Holt GM, Stockley I, Elson RA, Ibbotson C. A comparison of the performance of irradiated and non-irradiated bone graft in hip surgery. J Bone Joint Surg [Br] 1996;78-B:Supp I:70.

17. Ling RSM, Timperley AJ, Linder L. Histology of cancellous impaction grafting in the femur: a case report. J Bone Joint Surg [Br] 1993;75-B:693-6.

18. Schreurs BW, Buma P, Huiskes R, Slagter JL, Slooff TJ. Morsellized allografts for fixation of the hip prosthesis femoral component: a mechanical and histological study in the goat. Acta Orthop Scand 1994;65:267-75

19. Nelissen RG, Bauer TW, Weidenhielm LR, Le Golvan DP, Mikhail WE. Revision hip arthroplasty with the use of cement and impaction grafting: histological analysis of four cases. J Bone Joint Surg [Am] 1995;77-A:412-22.

20. Stevenson S, Horowitz M. The response to bone allografts. J Bone Joint Surg [Am] 1992;74-A:939-50.
21. Berrey BH, Lord CF, Gebhardt MC, Mankin HJ. Fractures of allografts. J Bone Joint Surg [Am] 1990;72-A:825-33.

22. Stevenson S, Shaffer JW, Goldberg VM. The humoral response to vascular and non-vascular allografts of bone. Clin Orthop 1996; 323:86-95.

23. Stevenson S, Emery SE, Goldberg VM. Factors affecting bone graft incorporation. Clin Orthop 1996;323:66-74.

24. Michaud RJ, Drabu KJ. Bone allograft banking in the United Kingdom. J Bone Joint Surg [Br] 1994;76-B:350-1.

25. The collection and storage of bone allografts. London: British Orthopaedic Association, 1992.

26. Kearney JN. Technical manual for musculo-skeletal tissues. Wakefield: British Association of Tissue Banks, 1996.

27. Unlinked Anonymous HIV Serosurveys Steering Group, Department of Health. Unlinked anonymous HIV seroprevalence monitoring programme in England and Wales. London: Department of Health, 1995.

28. Tomford WW. Transmission of disease through transplantation of musculoskeletal allografts. J Bone Joint Surg [Am] 1995;77-A: 1742-54.

29. Warwick RM, Eastland T, Fehily D. Role of blood transfusion service in tissue banking. Vox Sanguinis 1996;71:71-7.

30. Ivory JP, Thomas IH. Audit of a bone bank. J Bone Joint Surg [Br] 1993;75-B:355-7.

31. Gibbs CJ Jr, Gajdusek DC, Latarjet R. Unusual resistance to ionising radiation of the viruses of kuru, Creutzfeldt-Jacob disease and scrapie. Proc Natl Acad Sci USA 1978;75:6268-70.

32. Campbell DG, Li P, Stephenson AJ, Oakeshott RD. Sterilization of HIV by gamma irradiation: a bone allograft model. Int Orthop 1994; 18:172-6.

33. Fideler BM, Vangsness CT Jr, Moore T, Li Z, Rasheed S. Effects of gamma irradiation on the human immunodeficiency virus: a study in frozen human bone-patellar ligament-bone grafts obtained from infected cadavera. J Bone Joint Surg [Am] 1994;76-A:1032-5.

34. Pelker RR, Friedlaender GE. Biomechanical aspects of bone autografts and allografts. Orthop Clin North Am 1987;18:235-9.

35. Burwell RG. Studies in the transplantation of bone. VIII. Treated composite homograft-autografts of cancellous bone: an analysis of inductive mechanisms in bone transplantation. J Bone Joint Surg [Br] 1966;48-B:532-66.

36. Jackson DW, Windler GE, Simon TM. Intraarticular reaction associated with the use of freeze-dried, ethylene oxide-sterilized bonepatella tendon-bone allografts in the reconstruction of the anterior cruciate ligament. Am J Sports Med 1990;18:1-11.

37. Uemura Y, Yang YHJ, Heldebrant CM, Takechi K, Yokoyama K. Inactivation and elimination of viruses during preparation of human intravenous immunoglobin. Vox Sang 1994;67:246-54.

38. Deijkers RLM, Bloem RM, Petit PLC, et al. Contamination of bone allografts. J Bone Joint Surg [Br] 1997;79-B:161-6. 